\title{
PENGARUH PENYULUHAN METODE STIMULASI GAME PADA KADER DALAM MEMBERI STIMULASI KOGNITIF ANAK STUNTING DI WILAYAH PUSKESMAS KENJERAN
}

\author{
Diyah Arini ${ }^{1}$, Dwi Ernawati ${ }^{2}$, Qori' ila Saidah ${ }^{3}$ \\ 1,2,3 STIKES Hang Tuah Surabaya \\ Email : diyaharini76@yahoo.co.id, Ip3mSHT@stikeshangtuah-sby.ac.id
}

\begin{abstract}
ABSTRAK
Perbedaan tingkat kecerdasan pada anak stunting yang lebih rendah dibandingkan anak normal lainnya perlu mendapatkan penanganan khusus. Orang tua dan kader yang paling utama bertugas memberikan stimulasi kecerdasan kepada anak. Pemberian pendidikan kesehatan kepada keluarga dan kader yang konvensional membuat materi yang diberikan tidak dapat diterima dengan baik. Kegiatan pengabdian masyarakata ini bertujuan untuk meningkatkan pengetahuan para kader dalam memberikan stimulasi kognitif pada anak stunting di wilayah Kenjeran Surabaya. Metode kegiatan berupa pendidikan kesehatan dengan model simulation game ular tangga yang dilakukan pada tanggal 14 - 15 Desember 2019 kepada 110 kader kesehatan pada 4 Kelurahan antara lain Kelurahan Kenjeran, Kelurahan Bulak, Kelurahan Kedung Cowek, dan Kelurahan Sukolilo. Luaran berdasarkan capaian implementasi yang dilaksanakan adalah perubahan pengetahuan dan sikap kader kesehatan dan ibu wilayah pesisir yang diberikan pendidikan kesehatan dengan metode simulation game ular tangga dalam memberikan stimulasi gangguan perkembangan kognitif pada anak stunting.
\end{abstract}

Kata Kunci : Stunting, Kognitif, Pendidikan Kesehatan, Simulation Game

\section{ABSTRACT}

Differences in the level of intelligence in children stunting is lower than other normal children need special attention. Parents and foremost cadres in charge of providing stimulation to the child's intelligence. The provision of health education to families and cadres were conventionally made of the material provided can not be well received. This community service activity helped increase the knowledge of cadres in providing cognitive stimulation to stunting children in the Kenjeran region of Surabaya. The purpose of this study was to analyze the influence of methods of simulation games on the knowledge and attitude of cadres in child stunting provide cognitive stimulation. The method of activity is in the form of health education with a simulation game of the snake and ladder game conducted on 14 - 15 December 2019 to 110 health cadres in 4 kelurahan including kelurahan Kenjeran, Kelurahan Bulak, Kelurahan kedung Cowek and kelurahan Sukolilo. Outcome based on implemetation achievements carried out is a change in knowledge and attitudes of health cadres of coastal areas given health education with the simulation game method of snakes and ladders in providing simulation of cognitive developmental disorders in stunting children.

Keywords : Stunting, Cognitive, Health Education, Simulation Game 


\section{PENDAHULUAN}

Stunting menggambarkan status gizi kurang yang bersifat kronik pada masa pertumbuhan dan perkembangan sejak awal kehidupan. Menurut penelitian [1] didapatkan hasil bahwa terdapat hubungan yang signifikan antara stunting dengan skor IQ anak usia sekolah dasar dari keluarga miskin, pada anak dengan stunting mendapatkan score IQ yang lebih rendah 10-15 point dari anak normal [1]. Hasil IQ yang lebih rendah dari anak lain yang tidak menderita stunting membuat anak-anak dengan stunting memerlukan stimulasi yang lebih banyak dibanding dengan anak yang tidak menderita stunting [2]. Peran kader kesehatan dan orang tua menjadi sangat penting sebagai support system terdekat dari anak dengan stunting. Orang tua dan kader berperan memberikan stimulasi secara terus menerus untuk mengejar ketertinggalan perkembangan kognitif anak dengan stunting.

Penelitian yang dilakukan di Kabupaten Jatinangor menyatakan lebih dari $50 \%$ kader masih memiliki pengetahuan kurang mengenai perkembangan dari balita [3].

Secara global, pada tahun 2012 prevalensi anak pendek sebesar 171 juta anak-anak di mana 167 juta atau sekitar 96\% kejadian terjadi di negara berkembang, seperti Afrika dan Asia [4]. Data dan informasi dari Kementrian Kesehatan Republik Indonesia menunjukkan persentase balita pendek yang terdapat di Indonesia pada tahun 2007 sebesar $36,8 \%$, tahun 2013 sebanyak 37,2\%, pada tahun 2018 sebesar 30,8\%. Menurut hasil Pemantauan Status Gizi 2017 didapatkan 18,0 \% balita di Jawa Timur memiliki tinggi badan yang pendek dengan 5,1 sangat pendek dan 12,9 balita pendek. Riskesdas 2013 Jawa Timur merupakan salah satu provinsi yang memiliki prevalensi stunting tinggi yaitu $35,1 \%$.

Hasil yang berbeda didapatkan pada Rikesdas 2018 dimana angka prevalensi balita stunting di provinsi Jawa Timur sebesar 22,9\% atau hampir seperempat dari jumlah penduduk di Jawa Timur didapatkan data di 63 Puskesmas wilayah Surabaya tahun 2015-2016 dengan jumlah 
balita stunting 24.912 dengan presentase 14,86\% [5]. Sementara itu menurut penelitian mengenai tingkat pengetahuan, sikap, lama menjadi kader dan frekuensi mengikuti pelatihan yang dilakukan di Semarang menunjukan hasil 46,8 \% kader memiliki pengetahuan kurang, 34,3\% kader memiliki pengetahuan cukup, dan hanya $17,1 \%$ kader memiliki pengetahuan baik. Dari penelitian yang sama pula mengenai sikap didapatkan 51,4\% kader memiliki sikap yang tidak sesuai terkait penanganan gizi dan $48,6 \%$ kader memiliki sikap yang sesuai [6]. Wilayah Puskesmas Kenjeran sendiri memiliki 30 Posyandu dengan total 150 orang kader. Pada saat dilakukan studi pendahuluan oleh peneliti dengan menggunakan metode diskusi di dapatkan dari 3 kader kesehatan di sekitar Puskesmas Kenjeran hanya 1 orang yang mempu menyebutkan definisi dan penyebab dari stunting namun tidak tahu cara memberikan stimulasi kognitif anak dengan stunting dan sisanya tidak tahu sama sekali megenai stunting.

Kader kesehatan dan orang tua bertugas untuk memberikan stimulasi secara terus menerus dan untuk melakukan stimulasi kognitif dibutuhkan pengetahuan dan sikap yang cukup. Metode ceramah adalah cara yang yang digunakan dalam menyampaikan pesan kesehatan dan informasi kepada individu, kelompok dan masyarakat secara lisan. Metode ini baik untuk sasaran yang berpendidikan tinggi maupun rendah [7]. Untuk persiapan dan pelaksanaanya adalah penceramah harus mempunyai sikap dan penampilan yang menyakinkan dan tidak raguragu, sebelum memberkikan ceramah harus mempersiapkan dan mempelajari materi serta mempersiapkan alat bantu pengajaran misalnya slide sound system dan sebagainya [7]. Untuk kelemahan metode ini adalah bersifat memaksa, membuat individu, kelompok ataupun masyarakat yang diberi ceramah bersifat pasif dan apabila terlalu lama kadang membosankan [8]. Permainan simulasi adalah salah satu metode pembelajaran atau pendidikan yang melibatkan pembelajaran berdasarkan pengalaman [9]. 
Permainan simulasi adalah kegiatan yang dirancang untuk meniru realitas dunia luar, di dalam kelas, dengan tujuan yang ditentukan khusus. Game simulasi bisa berikan kesempatan bagi siswa untuk terlibat dalam proses pembelajaran yang akan menghasilkan sistem pembelajaran aktif karena akan fokus pada audience. Simulation Game selain dapat membuat audience tertarik juga sangat efektif memberikan transfer ilmu dan pengetahukan serta perubahan sikap dari audience.

\section{METODE PELAKSANAAN}

\section{Tempat dan Waktu}

Kegiatan pengabdian masyarakat ini dilakukan oleh tim Keperawatan Anak Stikes Hang Tuah Surabaya pada tanggal 14-15 Desember 2018 di Kelurahan kenjeran kepada kader kesehatan Kelurahan Kenjeran, Kelurahan Bulak, Kelurahan Kedung Cowek, dan Kelurahan Sukolilo

\section{Tahapan dan metode pelaksanaan kegiatan}

Metode yang digunakan dalam kegiatan ini kader kesehatan dilakukan pre test terhadapap pengetahuan dan sikap para kader kesehatan dan didapatkan hasil pengetahuan baik 18,2 \%, cukup 34,5\% kurang 47,3\%, sikap yang mendukung 21,8\% serta sikap yang tidak mendukung $78,2 \%$. Setelah itu para kader diberikan pendidikan kesehatan tentang stimulasi gangguan perkembangan anak stunting dengan metode simulation game ular tangga. Setelah itu dilakukan post test untuk menilai pengetahuan dan sikap para kader dan didapatkan hasil pengetahuan baik 30,9\%, cukup 60,1\%, kurang $0 \%$ sedangkan sikap kader yang mendukung $100 \%$.

\section{Persiapan Alat dan Bahan}

Peralatan yang digunakan dalam kegiatan pengabdian masyarakat ini beruba media pendidikan kesehatan metode simulation game Ular tangga berupa spanduk dengan gambar permainan ular tangga $4 \times 6 \mathrm{~m}^{2}$ 
dimana dalam setiap kotak terdapat pertanyaan dan jawaban seputar stimulasi perkembangan kognitif yang diberikan pada anak stunting sesuai usia, alat tulis, Leaflet.

\section{Evaluasi}

Evaluasi kegiatan dengan menggunakan kuisioner pre test dan post test.

\section{HASIL DAN PEMBAHASAN}

Pengetahuan seseorang akan berubah seiring dengan setiap hal yang dialami seseorang selama bertahun-tahun dan pengetahuan diperoleh dari pengalaman sendiri atau orang lain yang melibatkan apa yang dialami oleh panca indra. Peneliti berasumsi pengalaman yang dimiliki oleh kader dapat digunakan untuk memecahkan masalah yang sering dihadapi hanya mungkin kader perlu diberikan pengetahuan untuk dapat merubah sikapnya [8].

Salah satu faktor yang mempengaruhi sikap seseorang adalah pengaruh dari kebudayaan. Dari total hampir seluruhnya 101 (91.8\%) bersuku Jawa dan sebagian kecil $9(8.2 \%)$ responden berasal dari Suku Madura. Budaya sebagai seperangkat nilai, kepercayaan, kebiasaan, keinginan dan perilaku yang dipelajari oleh masyarakat sebagai sebuah pedoman dalam membentuk perilaku [10]. Peneliti berasumsi kebudayan responden yang mayoritas adalah suku jawa membuat akses kepada perubahan sikap yang lebih baik semakin mudah karena fasilitas dan tata norma sosial yang diajarkan sejak dahulu.

Pendidikan tentunya berpengaruh sangat besar terhadap perubahan sikap seseorang. Dari data didapatkan para kader memiliki pendidikan SLTA dan sebagian kecil lainnya pernah menempuh pendidikan di perguruan tinggi dan masih ditemukan kader yang berpendidikan SLTP.

Hal lain yang dapat mempengaruhi pengetahuan adalah tingkat pendidikan. Semakin tinggi pengetahuan seseorang maka akan semakin 
baik pula pengetahuan yang dimiliki orang tersebut [8]. Riwayat pendidikan responden yang sebagian besar SLTA dan masih ditemukan responden yang berpendidikan SLTP sedikit banyak mempengaruhi penerimaan responden mengenai pengetahuan dan kemampuan dalam membuka diri dan menerima perubahan terutama perubahan sikap.

Media informasi atau media masa semakin berkembang pesat pada akhir-akhir ini sehingga berpotensi untuk memberikan pengetahuan, baik yang positif maupun yang negatif. Para kader menggunakan media informasi televisi di rumah mereka dan hanya sebagian kecil yang menggunakan jaringan internet sebagai media informasi mereka. Namun sebagian besar memiliki HP android sehinggan dengan mudah mendapatkan informas tentang pertumbuhan dan perkembangan anak melalui gadget. Peningkatan pengetahuan tidak mutlak diperoleh pendidikan formal, akan tetapi juga dapat diperoleh pada pendidikan non formal seperti didapat dari seminar atau pelatihan serta mencari informasi dari media massa seperti internet, buku, televise [7]. Sehingga sangat mungkin perubahan sikap terjadi mengingat semakin mudahnya akses untuk mencari informasi, meningkatkan pengetahuan dan merubah sikap responden terhadap sesuatu masalah yang sedang terjadi.

Pengetahuan merupakan domain yang sangat penting dalam terbentuknya tindakan seseorang. Sehingga peneliti berasumsi berubahnya sikap responden dipengaruhi oleh tingkat pengetahuan yang mereka miliki pula, semakin tinggi tingkat pengetahuan responden akan semakin terbuka pula pemikiran responden untuk bersikap terhadap lingkungannya dan perubahan pengetahuan responden salah satunya seperti yang dijelaskan diatas dipengaruhi oleh pemberian pendidikan kesehatan dalam hal ini pemberian pendidikan kesehatan dengan menggunakan metode simulation game [11].

Proses penerimaan informasi dengan permainan ular tangga akan memiliki intensitas yang tinggi untuk mempersepsikan sebuah informasi dibandingkan dengan melakaukan ceramah. Saat para kader memainkan 
ular tangga, indra yang digunakan selain mata adalah telinga. Semua panca indra merupakan jalur penerimaan informasi ke otak, semakin banyak indra yang digunakan dalam penyampaian informasi maka akan semakin banyak infromasi yang akan diterima dan yang akan disimpan. Saat kade kesehatan melakukan permainan ular tangga ini mereka akan membaca pertanyaan atau perintah dan melihat gambar yang terdapat dalam pemainan ular tangga serta menjawab pertanayaan sesuai perintah.

Kemampuan seseorang untuk dapat mengingat suatu informasi, akan meningkat lebih tinggi bila mempelajari suatu materi dengan metode membaca, karena dengan membaca kemampuan mengingat akan meningkat $72 \%$ sesudah 3 jam, dalam permainan ular tagga ini para kader kesehatan akan membaca pertanyaan dari kartu-kartu pertanyaan yang ada didalam permainan ular tangga segingga akan meningkatkan kemampuan mengingat kader kesehatan terhadap soal-soal yang berghubungan dengan stimulasi perkembangan kognitif pada anak stunting [12].

Simulation game permainan ular tangga ini dapat memberikan umpan balik secara langsung kepada kader kesehatan, umpan balik ini dilakukan dengan cara membahas jawaban kuisioner dalam bentuk kartu pertanyaan yang sudah disberikan agar dapat mengevaluasi jawaban masing-masing kader kesehatan sehingga kebenaran informasi yang diterima oleh para kader kesehatan dapat langsung diterima oleh kader kesehatan [13]. Permainan ular tangga ini dilakukan dalam kelompok kecil 10 orang sehingga dengan jumalh anggota pemain yang sedikit maka suasana dangat mudah dikendalikan dan tidak akan terdistraksi dengan hal-hal yang dapat memcahkan konsentrasi sehingga informasi yang diterima dapat mudah dicerna [12].

Simulation game dengan permainan ular tangga ini juga merupakan salah satu metode pembelajaran kooperatif dimana memberikan kesempatan kepada kader kesehatan untuk melakukan interaksi dan 
berpartisipasi aktif selama kegiatan berlangsung sehingga dapat mengembangkan secara mandiri melalui proses berpikirnya dalam mengolah informasi, sehingga metode pendidikan dengan Simulation game permainan ular tangga sangat efektif sekali dalam meningkatkan pengetahuan dan sikap para kader kesehatan.

\section{SIMPULAN DAN SARAN}

\section{Simpulan}

Berdasarkan hasil dan pembahasan terjadi perubahan pengetahuan dan sikap antara responden yang diberikan pendidikan kesehatan dengan metode simulation game dibandingkan dengan responden yang tidak diberikan.

\section{Saran}

Metode simulation game sangat efektif untuk digunakan sebagai sarana pemberian informasi dan pendidikan kesehatan yang dapat diaplikasikan di masyarakat.

\section{UCAPAN TERIMAKASIH}

1. Kepala Puskesmas Kenjeran

2. Kepala Kelurahan Kenjeran, Kelurahan Bulak, Kelurahan Kedung Cowek, dan Kelurahan Sukolilo

3. Kader Kesehatan di wilayah puskesmas Kenjeran

4. Ketua Stikes Hang Tuah Surabaya, Seluruh dosen, staf kependidikan, mahasiswa Stikes Hang Tuah Surabaya

5. Biro LP3M yang telah mendanai kegiatan pengabdian masyarakat

\section{DAFTAR PUSTAKA}

1. Yunitasari L. Perbedaan Intelegence Quotient (IQ) Antara Anak Stunting dan Tidak Stunting Umur 7 - 12 Tahun di Sekolah Dasar. 
2012;1.

2. Sedayu. Pengaruh Pemberian Stimulasi Pada Perkembangan Anak Usia 12-36 Bulan di Regency Sedayu Bantul. Bantul. 2016;

3. Agustin. Gambaran Pengetahuan Kader di Posyandu CipancingTentang Perkembangan Pada Balita. Unpad. 2015;

4. Lppm M, Hang S, Pekanbaru T. Permasalahan Anak Pendek (Stunting) dan Intervensi untuk Mencegah Terjadinya Stunting (Suatu Kajian Kepustakaan) Stunting Problems and Interventions to Prevent Stunting (A Literature Review). J Kesehat Komunitas. 2015;2(6):25461.

5. Depkes RI, Depkes. Riskesdas 2018. 2018.

6. Rizqa A. Lama Menjadi Kader, Frekuensi Pelatihan, Pengetahuan Gizi, dan Sikap kaderPosyandu dengan PerilakuPenyampaianInformasi Tentang Pesan Gizi Seimbang. Unpad. 2011;

7. Soekidjo Notoatmodjo. Promosi kesehatan Teori dan Aplikasi. Jakarta: Rineka Cipta; 2012.

8. Soekidjo Notoatmodjo. IImu Perilaku Kesehatan. Jakarta: Rineka Cipta; 2010.

9. Hidayatno A. Development of a Production Planning and Control Simulation Game To Enhance Learning Experience. 2005;(2).

10. Kotler A. Prinsip Pemasaran. 4th ed. Jakarta: Erlangga; 2012.

11. Soekidjo Notoatmodjo. Promosi kesehatandan Perilaku Kesehatan. Jakarta: Rineka Cipta; 2015.

12. Affandi. Pelatihan Ketrampilan Melatih. Jar Nas PelatihanKlinikKesehatan Reproduksi. 2003;

13. Amalia. Efektifitas Permainan Ular tangga Untik Meningkatkan Pengetahuan Tentang Budaya Rokok Siswa Kelas VII dan VIII SMP Ma'Arif NU Tegal. 2010; 